BaCKGROUND: Human and rodent leukocytes express high levels of the glucocorticoid-inducible protein annexin 1 (ANXA1) (previously referred to as lipocortin 1). Neutrophils and monocytes have abundant ANXA1 levels.

Aim: We have investigated, for the first time, ANXA1 ultrastructural expression in rat eosinophils and compared it with that of extravasated neutrophils. The effect of inflammation (carrageenin peritonitis) was also monitored.

Methods: Electron microscopy was used to define the sub-cellular localisation of ANXA1 in rat eosinophils and neutrophils extravasated in the mesenteric tissue. A pair of antibodies raised against the ANXA1 N-terminus (i.e. able to recognise intact ANXA1, termed LCPS1) or the whole protein (termed LCS3) was used to perform the ultrastructural analysis.

Results: The majority of ANXA1 was localised in the eosinophil cytosol $(\sim 60 \%)$ and nucleus $(30-40 \%)$, whereas a small percentage was found on the plasma membrane $(<10 \%)$. Within the cytosol, the protein was equally distributed in the matrix and in the granules, including those containing the typical crystalloid. The two anti-ANXA1 antibodies gave similar results, with the exception that LCPS1 gave a lower degree of immunoreactivity in the plasma membrane. Inflammation (i.e. carrageenin injection) produced a modest increase in eosinophil-associated ANXA1 reactivity (significant only in the cytoplasm compartment). Extravasated neutrophils, used for comparative purposes, displayed a much higher degree of immunoreactivity for the protein.

Conclusion: We describe for the first time ANXA1 distribution in rat eosinophil by ultrastructural analysis, and report a different protein mobilisation from extravasated neutrophils, at least in this acute model of peritonitis.

Key words: Neutrophil, Lipocortin 1, Ultrastructure, Carrageenin, Peritonitis

\section{Annexin 1 localisation in tissue eosinophils as detected by electron microscopy}

\author{
Sonia M. Oliani ${ }^{1,2}$, Amilcar S. Damazo ${ }^{2}$ and Mauro \\ Perretti ${ }^{3, C A}$
}

${ }^{1}$ Department of Biology, IBILCE - UNESP, São José do Rio Preto, SP, Brazil; ${ }^{2}$ Department of Morphology, UNIFESP - EPM, São Paulo, SP, Brazil; and ${ }^{3}$ The William Harvey Research Institute, Bart's and The London, Queen Mary School of Medicine and Dentistry, Charterhouse Square, London EC1M 6BO, UK

\footnotetext{
${ }^{\mathrm{CA}}$ Corresponding Author

Tel: +442078826065

Fax: +44 2078826076

E-mail: M.Perretti@qmul.ac.uk
}

\section{Introduction}

Migration of eosinophils into specific tissue sites is a hallmark of allergic diseases such as asthma and allergic rhinitis. Eosinophil recruitment can contribute to the perpetuation of the condition by releasing tissue-damaging agents such as major basic protein, eosinophil peroxidase, lipid mediators and multipotent cytokines. ${ }^{1}$ Therefore, it is important to have a better understanding of the mechanisms involved in the selective migration of eosinophils from the blood to allergic tissues and the further activation of these cells in the tissue in response to specific stimuli. ${ }^{2}$

Glucocorticoid hormones are now used as first-line drugs for the treatment of asthma, and have wide applications in the therapeutic control of other allergic and inflammatory diseases. Inhibition of cytokinestimulated eosinophil survival is one of the important actions of glucocorticoids. ${ }^{3}$ One of the mechanisms responsible for glucocorticoid therapeutic efficacy is increased expression of the anti-inflammatory protein annexin 1 (ANXA1). ${ }^{4}$ Few studies have addressed the link between steroids and ANXA1 production from resident lung cells..$^{5-8}$ Similarly, even less studies have focused on ANXA1 and the eosinophil. In a murine model of an allergic air-pouch we found that endogenous ANXA1 did not mediate the anti-inflammatory effect of dexamethasone, ${ }^{9}$ and a similar finding was obtained with respect to chemokine-induced eosinophil trafficking in the skin. ${ }^{10}$ It is unclear whether these data generated in murine systems may be translated to other species, including man. 
A similar paucity of data exists with regard to ANXA1 expression/localisation and the eosinophil polymorphonuclear leukocyte. The study of Das et al. ${ }^{9}$ reported that mouse eosinophils contained ANXA1, as determined with a flow cytometric assay. A more recent study reported ANXA1 expression on the cell surface of human eosinophils and its modulation by incubation with fluticasone proprionate. ${ }^{11}$

The majority of ultrastructural studies performed so far on ANXA1 have focused on the neutrophil. In resting human neutrophils, large amounts of the protein (between 2 and $4 \%$ of total cytosolic proteins) are in the cytoplasm. ${ }^{12,13}$ A large proportion of the intracellular protein co-localises with the gelatinase granules, as determined by confocal and electron microscopy analyses. ${ }^{14}$ This pattern of ultrastructural distribution explains easily the rapid mobilisation of ANXA1 seen in vitro and in vivo when the neutrophil adheres to an endothelial monolayer. ${ }^{15,16}$

The present study was prompted to address the basic question of ANXA1 expression in the eosinophil, using a rat model of peritonitis.

\section{Materials and methods}

\section{Animals}

Male Sprague-Dawley rats (200-250 g body weight; Bantin and Kingman, Hull, UK) were maintained on a standard chow pellet diet with tap water ad libitum. Animals were housed at four animals per cage in a room with controlled lighting (lights on 08:00-20:00h) and temperature $\left(21-23^{\circ} \mathrm{C}\right)$. Rats were not used before 2-3 days after their arrival. Experimental work was performed according to Home Office regulations (Guidance on the Operation of Animals, Scientific Procedures Act 1986).

\section{Model of inflammation}

Experimental peritonitis was induced in rats $(n=5)$ by the intraperitoneal (i.p.) injection of $1.5 \mathrm{mg} / \mathrm{kg}$ of carrageenin (type lambda; Sigma Chemical Co., Poole, Dorset, UK) in phosphate-buffered saline (PBS) as recently described. ${ }^{16,17}$ Sham animals were treated with PBS alone $(n=5)$. In all cases, rats were sacrificed $4 \mathrm{~h}$ later. Animals were anaesthetised by injection with sodium pentobarbital $(50 \mathrm{mg} / \mathrm{kg})$ and perfused though the heart left ventricle with sterile saline $(30-50 \mathrm{ml}$ per rat) for $30-60 \mathrm{sec}$. This was followed by a slow infusion of $100 \mathrm{ml}$ of cold paraformaldehyde (2\% in PBS) lasting for 5-10 min.

Fixation, processing, and embedding for immunocytochemistry (electron microscopy)

After perfusion, fragments of the mesentery were fixed in $4 \%$ paraformaldehyde and $0.5 \%$ glutaralde- hyde, $0.1 \%$ sodium cacodylate buffer $(\mathrm{pH} 7.4)$ for $24 \mathrm{~h}$ at $4{ }^{\circ} \mathrm{C}$. They were then washed in sodium cacodylate, dehydrated through a graded series of ethanol, and embedded in LR Gold (London Resin Co., Reading, UK). ${ }^{16}$ Sections $(0.5 \mu \mathrm{m}$ thick) were stained with Toluidine blue for light microscope analysis and subsequent electron microscopy. For electron microscopy, sections (approximately $90 \mathrm{~nm}$ thick) were cut on an ultramicrotome (Reichert Ultracut, Leica, Austria) and placed on nickel grids for immunogold labelling.

\section{Post-embedding immunogold labelling}

To detect ANXA1 in the tissues, a recently established immunogold staining procedure was used. ${ }^{16}$ Sections of the mesenteric tissues were prepared for electron microscopy by standard methods. Briefly, mesentery was stained with uranyl acetate $(2 \% \mathrm{w} / \mathrm{v}$ in distilled water), dehydrated through increasing concentrations of ethanol (70-100\%) and embedded in LR Gold resin. Ultrathin sections were prepared and incubated with the following reagents at room temperature: (a) $0.1 \mathrm{M}$ PBS containing $0.1 \%$ egg albumin (PBEA); (b) $2.5 \%$ normal rabbit serum in PBEA for $1 \mathrm{~h}$; (c) two different anti-ANXA1 antibodies diluted 1:300 in PBEA:LCS3 and LCPS, a sheep polyclonal antibody raised against the $\mathrm{N}$-terminal peptide of human ANXA1 (peptide Ac2-26), ${ }^{18}$ with non-immune sheep serum used as the control of the reaction (final dilutions of 1:300 in PBEA); (d) after five washes (3 min each) in PBEA, with a donkey anti-sheep IgG (Fc fragment specific) antibody (1:50 in PBEA) conjugated to 15-nm colloidal gold (British Biocell, Cardiff, UK). After $1 \mathrm{~h}$ at $4^{\circ} \mathrm{C}$, sections were extensively washed in PBEA and then in distilled water. Ultrathin sections were stained with uranyl acetate and lead citrate before examination on a Jeol $1200 \mathrm{EX}$ II electron microscope, Jeol USA Inc., Peabody, MA.

\section{Data handling and statistical analysis}

Immunocytochemical analysis of eosinophil infiltrated in the perivascular connective tissue was performed with randomly photographed sections. ${ }^{16}$ The area of each eosinophil compartment (membrane, cytosol, granule and nucleus) was determined with a point-counting morphometric method using a square test grid with $8.7 \mathrm{~mm}$ spacing. ${ }^{17}$ The density of immunogold (number of gold particles $/ \mu \mathrm{m}^{2}$ ) was calculated and expressed for each cell compartment. Values are reported as the mean \pm SEM of the number of electron micrographs.

Statistical differences between means were determined by analysis of variance followed, if significant, by the Bonferroni test. A probability values less than 0.05 was taken as significant. 


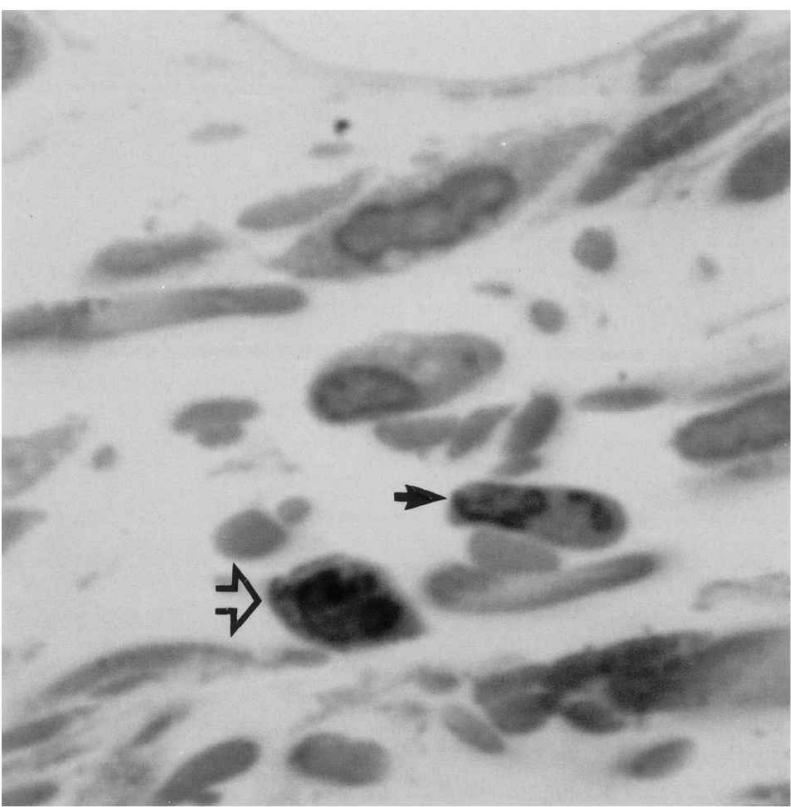

FIG. 1. Representative micrograph of the inflamed mesentery $4 \mathrm{~h}$ post-carrageenin injection. Carrageenin was injected i.p. to rats, and the mesenteric tissue collected $4 \mathrm{~h}$ later. Eosinophils can be seen localised both intravascularly as well as in the extravascular tissue (open arrow). An extravascular neutrophil is indicated (closed arrow). Sections $(0.5 \mu \mathrm{m})$ were stained with May-Grumwald and Giemsa $(\times 1500)$.

\section{Results}

\section{Carrageenin peritonitis}

In line with several studies, including our recent ones, ${ }^{16,17}$ carrageenin peritonitis is characterised by a rapid $(4 \mathrm{~h})$ and intense extravasation of blood-borne leukocytes into the mesenteric tissue, most of which are neutrophils (Fig. 1). However, we could also detect a small percentage of eosinophils in the tissue (as well as a certain number of resident macrophages) (Fig. 1).

\section{Ultrastructural analysis for ANXA1 in extravasated eosinophils}

The immunocytochemistry reaction with LCPS1, an antibody against the peptide $\mathrm{N}$-terminal of annexin 1 , showed the presence of gold particles on the nucleus and the cytosol of the eosinophils. Table 1 presents the quantitative data for the group injected with PBS, with a total of $(\sim 7 \pm 0.4) \times 10^{12}$ and $(9 \pm 0.8) \times 10^{12}$ of gold particles $/ \mu \mathrm{m}^{2}$ in the nucleus and the cytosol, respectively. Injection of carrageenin modestly elevated the ANXA1 immunoreactivity with a significant increase only in the cytoplasmic compartment (Table 1). Figure $2 \mathrm{~A}$ illustrates the staining obtained with LCPS1, and hence due to the intact protein. Figure 2B shows the result produced with LCS3. Table 1 shows that there was not much difference between the two antibodies in terms of total immunoreactivity.

In analogy to our previous study, ${ }^{16}$ the extravasated neutrophils presented a much higher degree of ANXA1 immunoreactivity (Fig. 2C).

A higher magnification of peritoneal eosinophil clarifies this aspect further (Figs 3 and 4). The reaction with LCS3 gave clearer results with apparent clusters of ANXA1 immunoreactivity on the cytoplasmic granules that contained the crystalloid (Fig. 3). Sites for expression of the protein in the cytosol and cytoplasmic vacuoles were also evident. Figure $4 \mathrm{~A}$ shows that intact ANXA1 was present in the granule as visualised with LCPS1, whereas Fig. $4 \mathrm{~B}$ confirms the specificity of the staining produced, with essentially an absence of gold particles following incubation with a control non-immune sheep serum.

\section{Discussion}

The present study reports for the first time the localisation of ANX-1 in the eosinophil in vivo as seen at the ultrastructural level. So far, the problem of ANX1 distribution in leukocytes has been predominantly

Table 1. Distribution of ANXA1 immunoreactivity in rat eosinophils in basal and inflammatory conditions

\begin{tabular}{|c|c|c|c|c|c|}
\hline \multirow[t]{2}{*}{ Treatment, staining antibody } & \multicolumn{5}{|c|}{ ANXA1 immunoreactivity (gold particles $/ \mu \mathrm{m}^{2}$ ) } \\
\hline & Nucleus & Cytosol & Granules & Membrane & Total \\
\hline $\begin{array}{l}\text { PBS, LCPS1 antibody } \\
\text { Carrageenin, LCPS1 antibody } \\
\text { Carrageenin, LCS3 antibody }\end{array}$ & $\begin{aligned} 7.2 & \pm 0.4 \\
9.7 & \pm 1.1 \\
10.9 & \pm 0.9\end{aligned}$ & $\begin{array}{l}6.2 \pm 0.6 \\
8.2 \pm 0.8^{*} \\
8.4 \pm 0.9^{*}\end{array}$ & $\begin{array}{l}3.9 \pm 0.5 \\
5.1 \pm 0.6 \\
5.2 \pm 1.0\end{array}$ & $\begin{array}{l}0.5 \pm 0.3 \\
0.9 \pm 0.2 \\
1.9 \pm 0.4^{*}\end{array}$ & $\begin{array}{l}16.4 \pm 0.8 \\
21.5 \pm 0.9^{*} \\
24.8 \pm 2.1^{*}\end{array}$ \\
\hline \multicolumn{6}{|c|}{$\begin{array}{l}\text { Rats were treated with PBS }(5 \mathrm{ml} / \mathrm{kg} \text { i.p.) or carrageenin }(1.5 \mathrm{mg} / \mathrm{kg} \mathrm{i.p.)} 4 \mathrm{~h} \text { prior to removal of the mesenteric tissue. Tissues were processes as } \\
\text { described in Materials and methods, and stained with either LCPS1 (a sheep serum raised against the ANXA1 N-terminus region, hence it } \\
\text { recognises intact ANXA1) or with LCS3 (a sheep serum raised against the entire protein, hence it recognises all ANXA1 species, including cleaved } \\
\text { forms that may be present). The number of gold particles/ } / \mathrm{m}^{2} \text { of cell area refers to the following cellular compartments: the nucleus, the plasma } \\
\text { membrane, the cytoplasmic matrix (cytosol) and the granule (clearly identified by the presence of the crystalloid). The total number is also } \\
\text { reported. Some tissue sections were also stained with a non-immune sheep serum, producing essentially no gold particle staining (see Fig. 4B } \\
\text { for a representative micrograph). Data are presented as the mean } \pm \text { SEM of } 10 \text { distinct eosinophils examined from the micrographs of the tissue } \\
\text { sections produced from three different rats. } \\
{ }^{*} p<0.05 \text { versus the corresponding PBS group value. }\end{array}$} \\
\hline
\end{tabular}




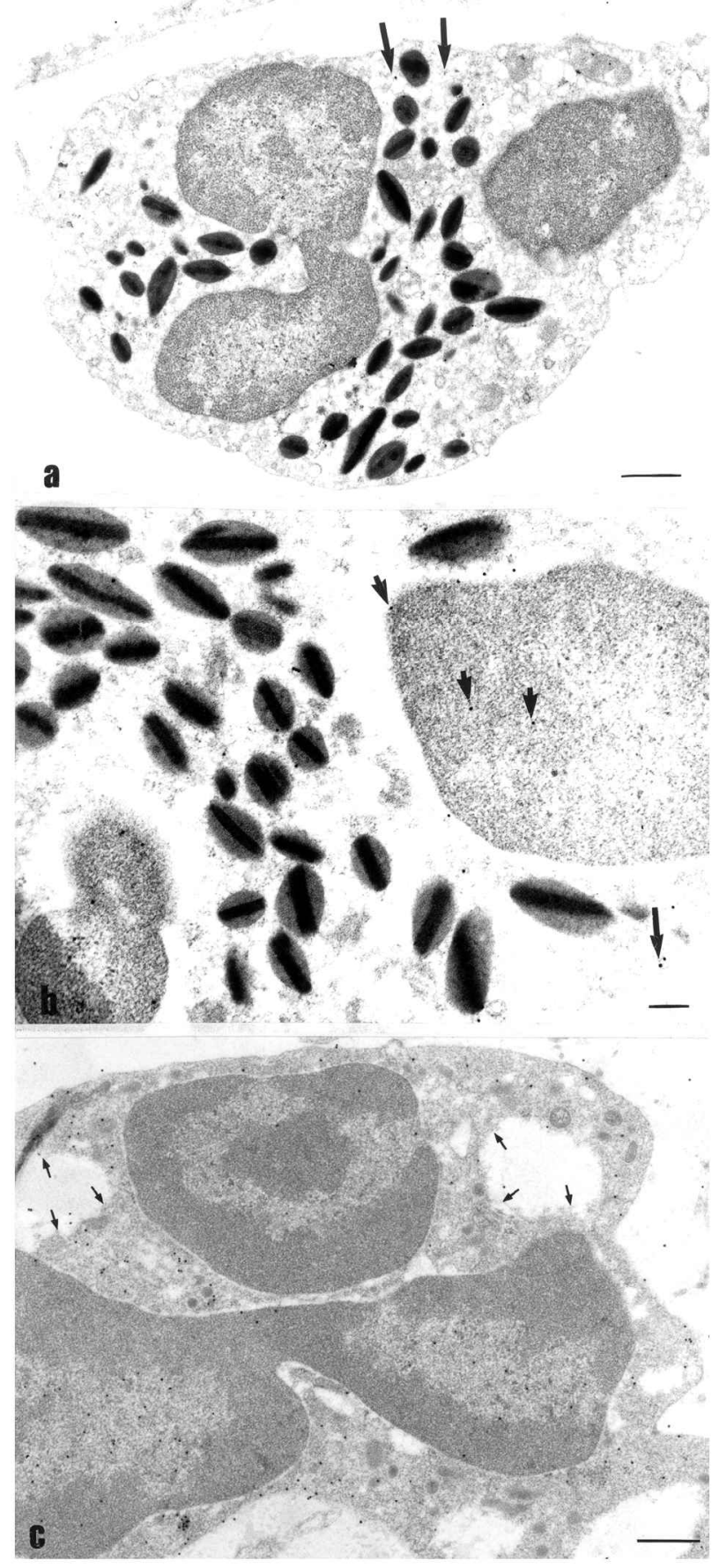

FIG. 2. Electron micrographs showing ANXA1 immunogold in extravascular eosinophils as detected by LCPS1 and LCS3 antisera. Treatment was as in Fig. 1. Sections were stained with a polyclonal sheep serum raised against the specific ANXA1 N-terminus (termed LCPS1) or with a polyclonal sheep serum raised against full-length human ANXA1 (termed LCS3). (A) LCPS1 staining for ANXA1 shows a significant proportion in the cytosol (arrows) and in granules. (B) Similar but more intense immunostaining with LCS3, with arrows highlighting gold particles in the cytosol and nucleus. (C) Extravasated neutrophils were greatly activated as indicated by the presence of large vacuoles in the cytosol (arrows). LCS3 produced an intense degree of immunoreactivity both in the cytosol and the nucleus. Bars: $(A)$ and $(C)$ $0.5 \mu \mathrm{m}$, (B) $0.2 \mu \mathrm{m}$.

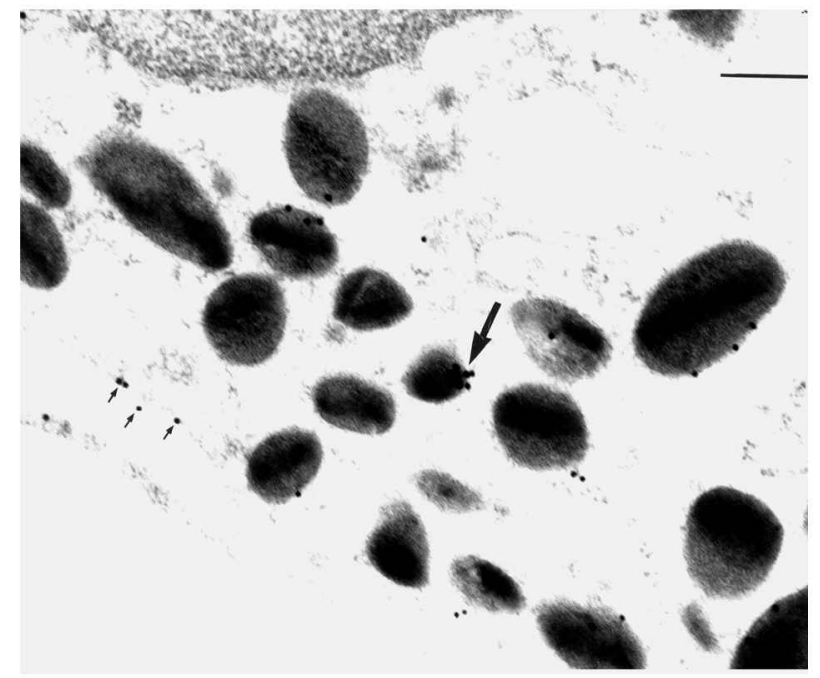

FIG. 3. ANXA1 protein expression in rat mesenteric eosinophils: LCS3 immunostaining. Treatment was as in Fig. 2, and endogenous ANXA1 immunoreactivity in an extravasated eosinophil was detected with LCS3. Gold particles are clearly evident both in granules (large arrow) as well as in cytoplasmic vacuoles (small arrows). Bar: $0.5 \mu \mathrm{m}$.

addressed in neutrophils, mast cells and macrophagelike cells. ${ }^{14,16,17,19,20}$

There is a vacuum in ANXA1 biology that is the expression and function that the protein may exert in the eosinophil polymorphonuclear leukocyte. As stated in the Introduction, both exogenous and endogenous ANXA1 did not seem to play a functional role in murine models of eosinophil extravasation. This may be a species-specific phenomenon or it may be characteristic of the skin microcirculation (since the two studies examined employed skin models of allergic inflammation). ${ }^{9,10}$ In fact, there are indications that ANXA1 may have functional roles in human systems during asthma and other pathologies characterised by eosinophil influx..$^{6,8,11}$

ANXA1 is a protein that lacks signal peptide, ${ }^{21}$ yet it is found in the extracellular medium, certainly in inflammatory conditions. ${ }^{22}$ Studies in the past 5 years have proposed that it is the extravasating neutrophil that brings ANXA1 into the inflamed tissue. ${ }^{16,22}$ In vitro, adherent neutrophils release ANXA1 ${ }^{15}$ as the result of a controlled process of exocytosis, ${ }^{14,16}$ probably linked to the specific localisation (in cytosolic granules) of the protein in this cell type. It is therefore possible that ANXA1 may play functional roles in eosinophils distinct from those that it plays in the neutrophil, and the initial reason for this may be simply linked to its localisation, hence its susceptibility to be mobilised during the process of extravasation.

In the present study we could demonstrate ANXA1 expression and distribution in the rat eosinophil. In analogy to other cell types, ANXA1 was found in the nucleus, the cytoplasm and also in close contact with 


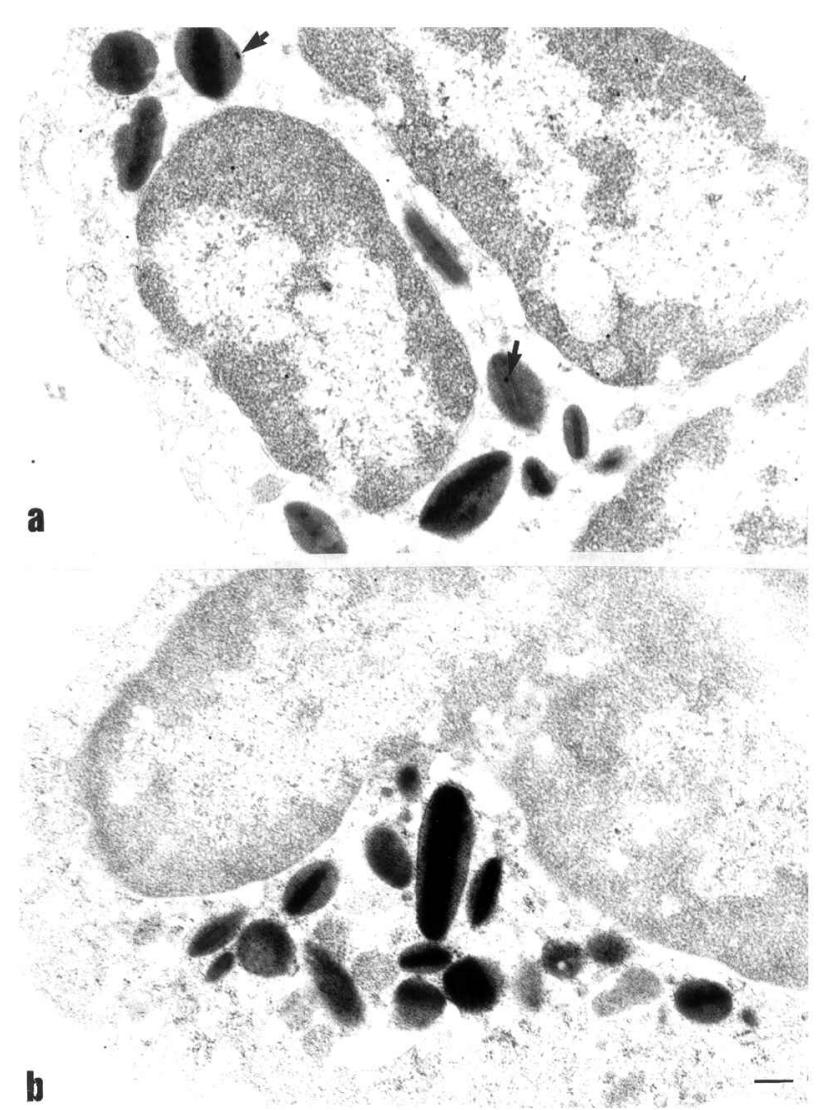

FIG. 4. Intact ANXA1 in rat mesenteric eosinophils: LCPS1 immunocytochemistry. Untreated rats were used for this staining. (A) Eosinophil view showing gold particles associated in the nucleus and specific granules (arrows). (B) Control section incubated with non-immune sheep serum. No gold labeling was observed. Bars: $0.2 \mu \mathrm{m}$.

the plasma membrane. This distribution is generally in line with observations made in other cells, such as neutrophils, mast cells and macrophages. A partial nuclear localisation for ANXA1 was initially reported in endothelial cells ${ }^{23}$ and then seen also in neutrophils and mast cells. ${ }^{16,17}$ The function of nuclear ANXA1 is presently obscure. Several groups have reported the existence of at least three sub-cellular pools of the protein. ${ }^{21,24,25}$ One pool is cytosolic, the second is strongly associated with the plasma membrane and can only be solubilised by zwitterionic detergents $^{26}$ (ANXA1 being an integral membrane protein), and the third pool is found loosely attached on the external leaflet of the plasma membrane (ANXA1 being a peripheral membrane protein, easily recovered by washing cells with ion chelators). Our electron microscopy analysis confirms this distribution of the protein in rat eosinophils, and sheds some light on its exact localisation in the cytoplasm. The majority of the protein $(\sim 60 \%)$ was found in the cytoplasmic matrix, whereas a lower degree was associated with the granules. Interestingly, apparent clusters of ANXA1 were seen in some of the characteristic eosinophil granules that contained the crys- talloid. This initial analysis shows a marked difference from the neutrophil, in which there is much more ANXA1 immunoreactivity (see reference 16 for rat neutrophils), and there is a larger granular portion. ${ }^{16,27}$

During the process of extravasation, leukocyte adhesion brings about a whole series of adhesion molecules and other proteins on the cell surface, through a process of controlled exocytosis. ${ }^{28,29}$ Cytoplasmic granules and/or vesicles fuse with the plasma membrane to increase the amounts of pro-inflammatory (adhesion molecules) and anti-inflammatory (ANXA1) mediators within that microenvironment. Regarding ANXA1, this model is valid for human ${ }^{15}$ and rodent neutrophils; ${ }^{16,30}$ however, it may be not true for the eosinophil. In essence, the lower degree of ANXA1 granular association demonstrated in rat eosinophil, as well as its lack of modulation by the inflammatory reaction (at variance from mast cells, for instance ${ }^{17}$ ), may suggest that a minor amount of the protein may be externalised upon eosinophil adhesion to the endothelium; hence, ANXA1 may have modest effects on the process of eosinophil trans-endothelial passage.

Based on analogy to the neutrophil and macrophage, eosinophil ANXA1 may modulate processes of exocytosis $^{31,32}$ or phagocytosis. ${ }^{20}$ Analysis of the inhibitory effects on eosinophil soluble lipid mediator generation $^{11}$ or radical species formation ${ }^{33}$ that endogenous ANXA1 may play could be the next step in an attempt to associate a functional role to the distribution presently reported. Similarly, ANXA1 localisation and function in the eosinophil may change after glucocorticoid treatment, and it may also be related to the tissue origin of the eosinophil (e.g. skin versus airways or peritoneum). In conclusion, this is the first ultrastructural study that has investigated ANXA1 distribution in the eosinophil. Future studies will address the potential functional role(s) for ANXA1 in this cell type.

\section{Acknowledgements}

This work was supported by the Funda ão de Amparo a Pesquisa do Estado de São Paulo (Fapesp), Brazil (to S.M.O.) and by an Arthritis Research Campaign fellowship to M.P. (grant P0567).

\section{References}

1. Gleich GJ, Adolphson CR, Leiferman KM. The biology of the eosinophilic leukocyte. Ann Rev Med 1993; 44: 85-101.

2. Minnicozzi M, Durán WN, Gleich GJ, Egan RW. Eosinophil granule proteins increase microvascular macromolecular transport in the hamster cheek pouch. J Immunol 1994; 153: 2664-2670.

3. Schleimer RP. Effects of glucocorticosteroids on inflammatory cells relevant to their therapeutic applications in asthma. Am Rev Resp Dis 1990; 141: S59-S69.

4. Barnes PJ. Anti-inflammatory actions of glucocorticoids: molecular mechanisms. Clin Sci 1998; 94: 557-572. 
5. Ambrose MP, Bahns C-L, Hunninghake GW. Lipocortin I production by human alveolar macrophages. Am J Respir Cell Mol Biol 1992; 6: 17-21.

6. Ambrose MP, Hunninghake GW. Corticosteroids increase lipocortin I in BAL fluid from normal individuals and patients with lung disease. $A m J$ Physiol 1990; 68: 1668-1671.

7. Ambrose MP, Hunninghake GW. Corticosteroids increase lipocortin I in alveolar epithelial cells. Am J Respir Cell Mol Biol 1990; 3: 349-353.

8. Smith SF, Tetley TD, Guz A, Flower RJ. Detection of lipocortin 1 in human lung lavage fluid: lipocortin degradation as a possible proteolytic mechanism in the control of inflammatory mediators and inflammation. Env Health Perspect 1990; 85: 135-144

9. Das AM, Flower RJ, Hellewell PG, Teixeira MM, Perretti M. A novel murine model of allergic inflammation to study the effect of dexamethasone on eosinophil recruitment. Br J Pharmacol 1997; 121: 97-104.

10. Teixeira MM, Das AM, Miotla JM, Perretti M, Hellewell PG. The role of lipocortin 1 in the inhibitory action of dexamethasone on eosinophil trafficking in cutaneous inflammatory reactions in the mouse. $\mathrm{Br} J$ Pharmacol 1998; 123: 538-544.

11. Sano A, Munoz NM, Sano H, et al. Inhibition of cPLA2 translocation and leukotriene C4 secretion by fluticasone propionate in exogenously activated human eosinophils. Am J Respir Crit Care Med 1999; 159: 1903-1909.

12. Ernst JD. Annexin functions in phagocytic leukocytes. In: Seaton BA, ed. Annexins: molecular structure to cellular function. Austin, TX: R.G. Landes Company, 1996: 81-96.

13. Perretti M. Endogenous mediators that inhibit the leukocyte-endothelium interaction. Trends Pharmacol Sci 1997; 18: 418-425.

14. Perretti M, Christian H, Wheller SK, et al. Annexin I is stored within gelatinase granules of human neutrophils and mobilised on the cell surface upon adhesion but not phagocytosis. Cell Biol Int 2000; 24 : 163-174.

15. Perretti M, Croxtall JD, Wheller SK, Goulding NJ, Hannon R, Flower RJ Mobilizing lipocortin 1 in adherent human leukocytes downregulates their transmigration. Nat Med 1996; 22: 1259-1262.

16. Oliani SM, Paul-Clark MJ, Christian HC, Flower RJ, Perretti M. Neutrophil interaction with inflamed postcapillary venule endothelium alters annexin 1 expression. Am J Pathol 2001; 158: 603-615.

17. Oliani SM, Christian HC, Manston J, Flower RJ, Perretti M. An immunocytochemical and in situ hybridization analysis of annexin 1 expression in rat mast cells: modulation by inflammation and dexamethasone. Lab Invest 2000; 80: 1429-1438.

18. Perretti M, Ahluwalia A, Harris JG, Goulding NJ, Flower RJ. Lipocortin-1 fragments inhibit neutrophil accumulation and neutrophil-dependent edema in the mouse: a qualitative comparison with an anti-CD11b monoclonal antibody. I Immunol 1993; 151: 4306-4314.

19. Majeed M, Perskvist N, Ernst JD, Orselius K, Stendahl O. Roles of calcium and annexins in phagocytosis and elimination of an attenuated strain of Mycobacterium tubercolosis in human neutrophils. Microb Pathogen 1998; 24: 309-320.
20. Kusumawati A, Liautard JP, Sri Widada J. Implication of annexin 1 in phagocytosis: effects of n-terminal domain deletions and point mutations of the phosphorylation site Ser-27. Cell Biol Int 2001; 25: 809-813.

21. Raynal P, Pollard HB. Annexins: the problem of assessing the biological role for a gene family of multifunctional calcium- and phospholipidbinding proteins. Biochim Biophys Acta 1994; 1197: 63-93.

22. Vergnolle N, Coméra C, Buéno L. Annexin 1 is overexpressed and specifically secreted during experimentally induced colitis in rats. Eur J Biocbem 1995; 232: 603-610.

23. Raynal $\mathrm{P}$ van Bergen PMP Hullin F et al. Morphological and biochemical evidence for partial nuclear localization of annexin I in endothelial cells Biochem Biophys Res Commun 1992; 186: 432-439.

24. Croxtall JD, Flower RJ. Lipocortin 1 mediates dexamethasone-induced growth arrest of the A549 lung adenocarcinoma cell line. Proc Natl Acad Sci USA 1992; 89: 3571-3575.

25. Peers SH, Smillie F, Elderfield AJ, Flower RJ. Glucocorticoid- and nonglucocorticoid induction of lipocortins (annexins) 1 and 2 in rat peritoneal leucocytes in vivo. Br J Pharmacol 1993; 108: 66-72.

26. Browning JL, Ward MP, Wallner BP, Pepinsky RB. Studies on the structural properties of lipocortin-1 and the regulation of its synthesis by steroids In: Melli M, Parente L, eds. Cytokines and lipocortins in inflammation and differentiation. New York: Wiley-Liss, 1990; 27-45.

27. Rosales JL, Ernst JD. Calcium-dependent neutrophil secretion: characterization and regulation by annexins. J Immunol 1997; 159: 6195-6202.

28. Borregaard N, Cowland JB. Granules of the human neutrophilic polymorphonuclear leukocyte. Blood 1997; 89: 3503-3521.

29. Gautam N, Olofsson AM, Herwald H, et al. Heparin-binding protein (HBP/CAP37): a missing link in neutrophil- evoked alteration of vascular permeability. Nat Med 2001; 7: 1123-1127.

30. Mancuso F, Flower RJ, Perretti M. Leukocyte transmigration, but not rolling or adhesion, is selectively inhibited by dexamethasone in the hamster post-capillary venule. Involvement of endogenous lipocortin 1. J Immunol 1995; 155: 377-386.

31. Meers P, Mealy T, Pavlotsky N, Tauber AI. Annexin I-mediated vesicular aggregation: mechanism and role in human neutrophils. Biocbemistry 1992; 31: 6372-6382

32. Meers P, Mealy T, Tauber AI. Annexin I interactions with human neutrophil specific granules: fusogenicity and coaggregation with plasma membrane vesicles. Biochim Biophys Acta 1993; 1147: 177-184.

33. Euzger HS, Flower RJ, Goulding NJ, Perretti M. Differential modulation of annexin I binding sites on monocytes and neutrophils. Med Inflamm 1999; 8: 53-62.

\section{Received 20 March 2002 \\ Accepted 27 May 2002}




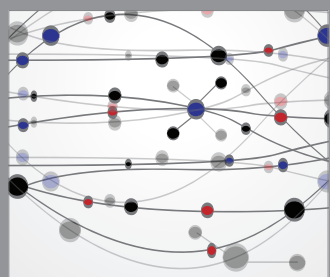

The Scientific World Journal
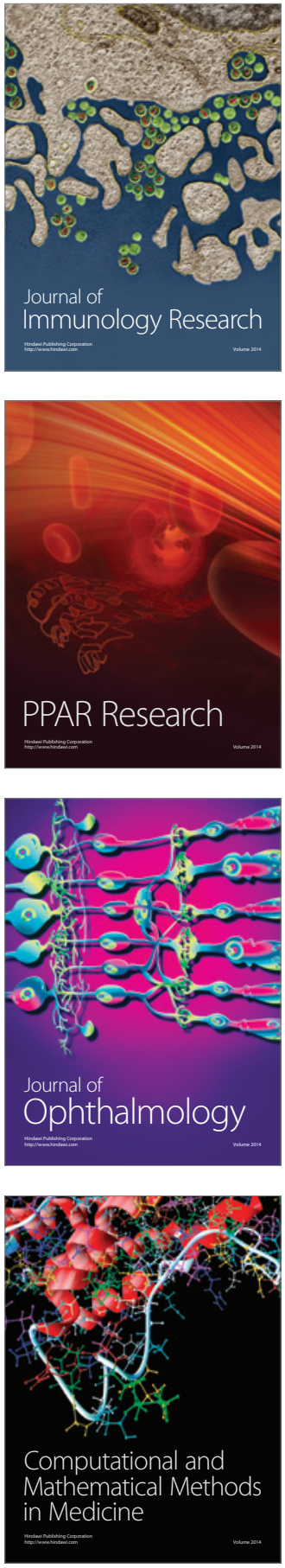

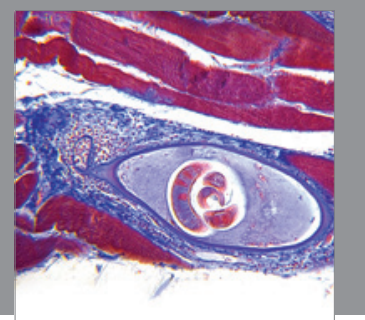

Gastroenterology

Research and Practice
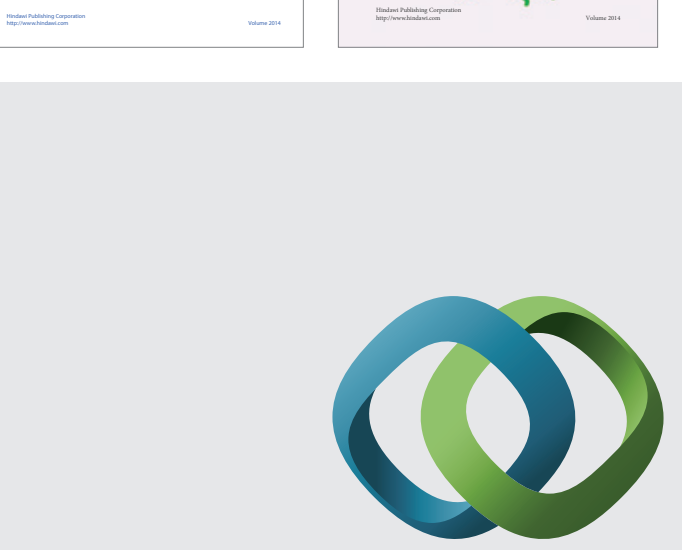

\section{Hindawi}

Submit your manuscripts at

http://www.hindawi.com
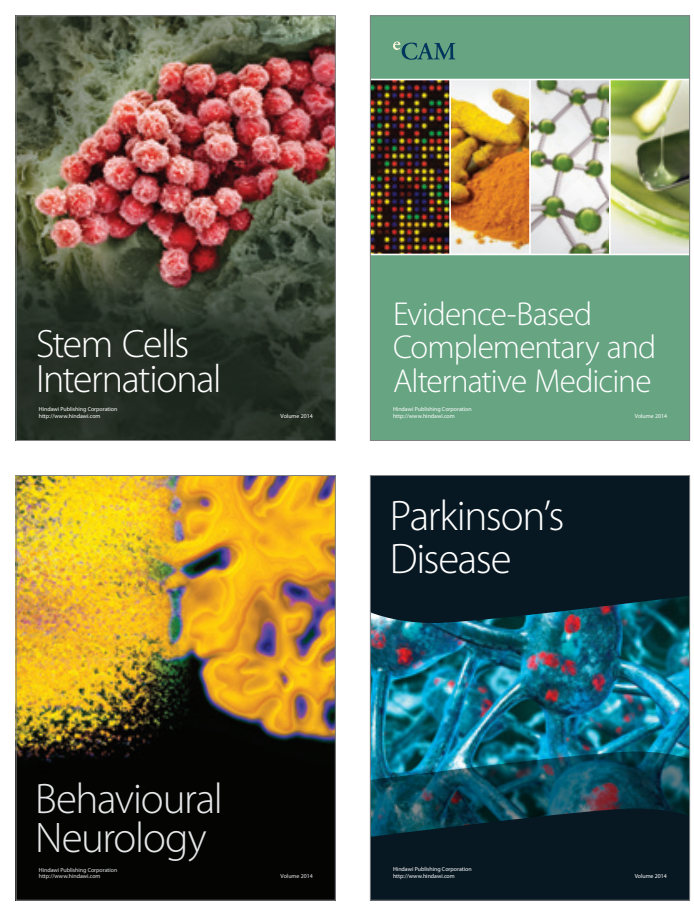

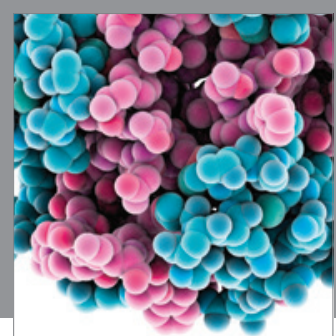

Journal of
Diabetes Research

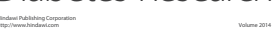

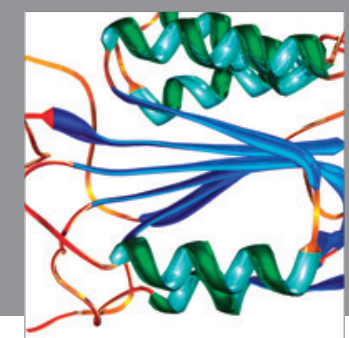

Disease Markers
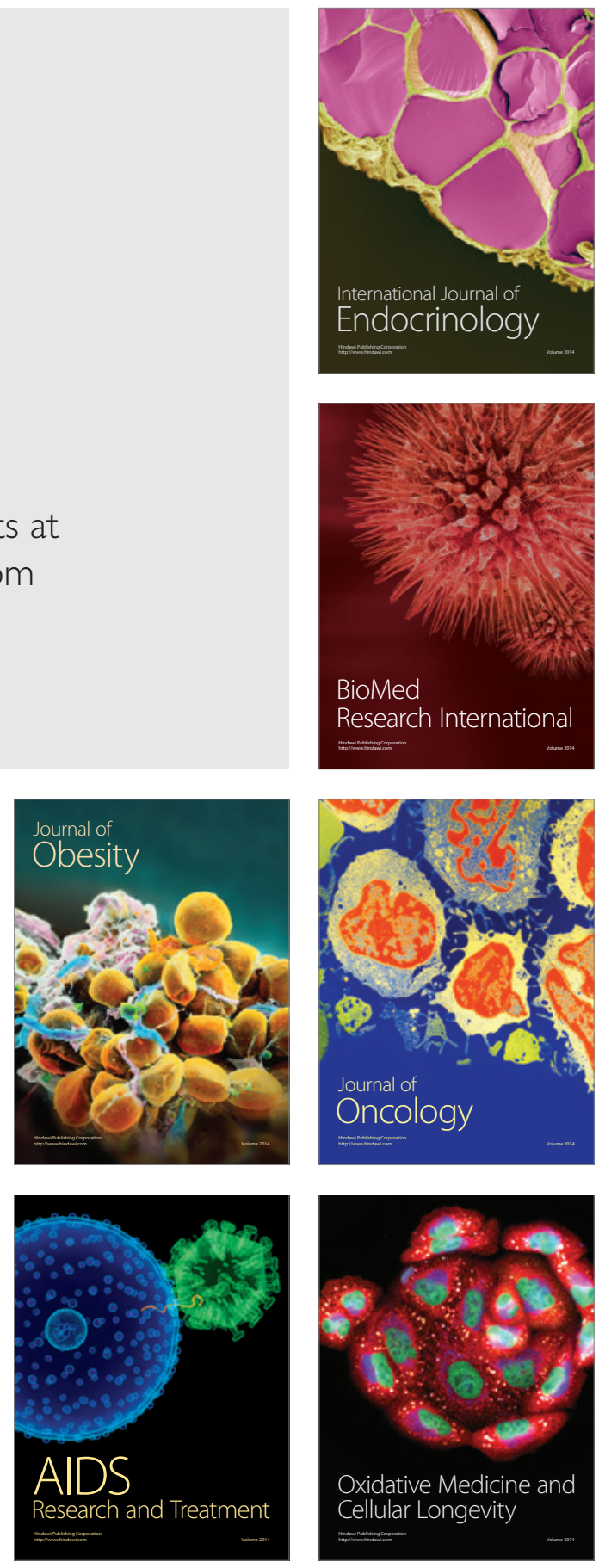